\title{
Studies Concerning the Dynamics of Productive Indicators on Gray Guinea Fowl (Numida Meleagris)
}

\author{
Dan Claudiu ROȘCA*, Marius Giorgi USTUROI \\ University of Agricultural Sciences and Veterinary Medicine „Ion Ionescu de la Brad”, Iași, Romania \\ *corresponding author: claudiu.rdc@gmail.com
}

Bulletin UASVM Animal Science and Biotechnologies 75(1)/ 2018

Print ISSN 1843-5262; Electronic ISSN 1843-536X

DOI:10.15835/buasvmcn-asb: 003417

\begin{abstract}
Growing guinea-fowls is an area of less research activity, although meat and eggs from this species are increasingly sought by consumers around the world. In addition, there is a number of very valuable biological features that makes this sector such attractive. This paper deals with a study on the productive performance of the gray guinea fowl under controlled ambient conditions. The biological material consisted of 50 specimens of guinea-fowls, purchased from a producer in our country. Those guinea fowls were grown according to the species-specific technology, from one day to 77 days. The target indicators were body weight, weight gain, feed consumption and stockholding proportion, determined in accordance with the poultry research methodology. The data were statistically processed using the Anova (Analysis of variance) program. For the gray guinea fowl, the growing period has been divided into three stages of age, differentiated by the protein level of the feed. At the time of population, the body weight of birds was $28.09 \pm 0.35 \mathrm{~g}$, and on the day of slaughter (77th day), $1923.76 \pm 18.29$ g. This weight was achieved with a feed conversion index of 1: 3.64 .

The gray guinea fowl exhibits good organic resistance and ensures satisfactory meat production under conditions of optimal nutrient feeding.
\end{abstract}

Keywords: body weight, consumption, guinea fowl

\section{INTRODUCTION}

Compared to other livestock breeding sectors, poultry farming is seen as an important and costeffective livestock production because, for a long time, domestic poultry have been grown only in small numbers and empirically, with no scientific concern about diet, shelter and rational care (Usturoi, 2008).

On animal protein assurance, a remarkable role is played by animal husbandry, and in this livestock sector, poultry farmin is a very important branch. Poultry, in addition to its fine taste, contains a lot of nutrients very useful for our body. It is especially appreciated as a source of animal protein with high nutritional value and low calories intake. That's why breeds for meat production have been created and based on these we got hybrids specialized in this direction; like goose, ducks, turkeys and even guinea fowl.

Growing guinea fowls can be a profitable business with the use of modern technology and a good quality biological material. Meat and eggs from those species are increasingly sought by consumers around the world.

Guinea fowl has a number of very valuable biological features that make this sector such attractive.

\section{MATERIALS AND METHODS}

The studied biological material consisted of 50 guinea fowls specimens, purchased from a producer in our country; were grown according to the species-specific technology, from $1^{\text {st }}$ day to $77^{\text {th }}$ day. During the research, one of the monitored 
Table 1. Dynamics of body weight on the studied birds

\begin{tabular}{ccccc}
\hline \multirow{2}{*}{ Age (weeks) } & \multicolumn{3}{c}{ Statistical estimators } \\
\cline { 2 - 5 } & mean $\pm \mathbf{s d}$ & $\mathbf{c v}$ & Min (g) & Max (g) \\
\hline $\mathbf{0}$ & $28.09 \pm 0.35$ & 9.02 & 23.57 & 34.77 \\
\hline $\mathbf{1}$ & $106.68 \pm 1.52$ & 9.92 & 85.34 & 136.88 \\
\hline $\mathbf{2}$ & $241.33 \pm 3.04$ & 8.71 & 202.18 & 290.56 \\
\hline $\mathbf{4}$ & $372.31 \pm 3.67$ & 7.14 & 321.77 & 424.32 \\
\hline $\mathbf{5}$ & $604.57 \pm 6.82$ & 8.03 & 426.98 & 666.53 \\
\hline $\mathbf{6}$ & $732.39 \pm 9.81$ & 9.46 & 474.55 & 832.06 \\
\hline $\mathbf{7}$ & $1109.08 \pm 11.28$ & 7.23 & 771.90 & 1224.33 \\
\hline $\mathbf{8}$ & $1258.79 \pm 11.84$ & 6.65 & 1009.83 & 1401.04 \\
\hline $\mathbf{9}$ & $1534.19 \pm 13.28$ & 6.34 & 1254.31 & 1699.89 \\
\hline $\mathbf{1 0}$ & $1681.55 \pm 16.07$ & 6.67 & 1441.02 & 1873.09 \\
\hline $\mathbf{1 1}$ & $1832.68 \pm 19.37$ & 7.38 & 1454.21 & 2109.32 \\
\hline & $1923.76 \pm 18.29 \mathrm{~g}$ & 6.94 & 1555.63 & 2235.45 \\
\hline
\end{tabular}

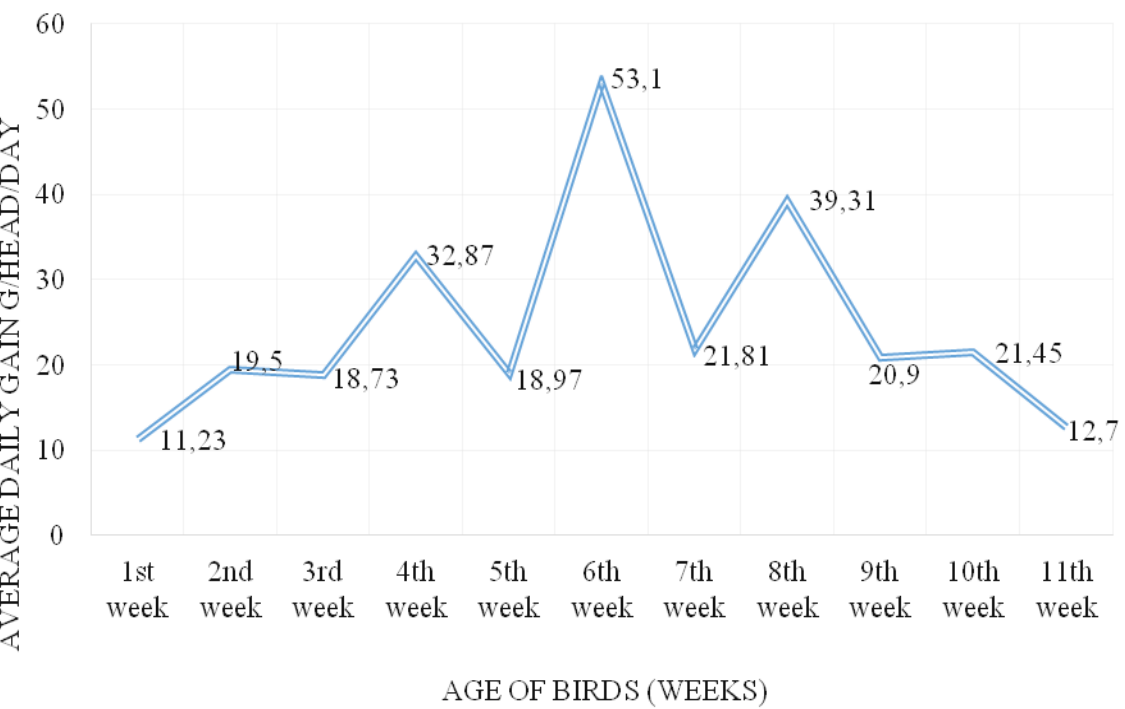

Figure 1. The average daily gain of the studied birds

indicators was the body weight by weighing individually the entire guinea fowl flock on the first day of each week using an electronic balance ATZ 1200 (Axis, Gdańsk, Poland). At the end of each week of life of guinea fowls, the average daily gain (ADG) according to the formula (Fw-Iw)/n, where Fw- final weight, Iw-initial weight, n-number of days, was calculated. Other indicators were the consumption of combined fooder (average daily consumption, feed conversion ratio) and stockholding proportion. The concentration of energy in the mixtures administered to the guinea fowl was about $2760 \mathrm{kcal} \mathrm{ME} / \mathrm{kg}$ feed with $27.44 \%$ CP within the first 21 days of age, after that we administered a mixture of $2651 \mathrm{kcal} \mathrm{ME} / \mathrm{kg}$ feed with $25.13 \%$ C.P. The stocking density was about
4.1 heads $/ \mathrm{m}^{2}$.The data was statistically processed using the Anova soft (Analysis of variance).

\section{RESULTS AND DISCUSSIONS}

Body weight is a factor that greatly condenses the quantitative and qualitative production of meat that can be obtained from a bird. On the first day of live, the registered body weights ranged between $23.57 \mathrm{~g}$ and $34.77 \mathrm{~g}$, the mean value for this moment of life was $28.09 \pm 0.35 \mathrm{~g}$. In the next periods, the body weight of the birds progressively increased, reaching $106.68 \pm 1.52 \mathrm{~g}$ at the end of the first week of life, $732.39 \pm 9.81 \mathrm{~g}$ at the end of $5^{\text {th }}$ week and $1923.76 \pm 18.29 \mathrm{~g}$ at the end of the growth period ( $77^{\text {th }}$ day). In terms of variability, the studied characteristic showed a fairly good 


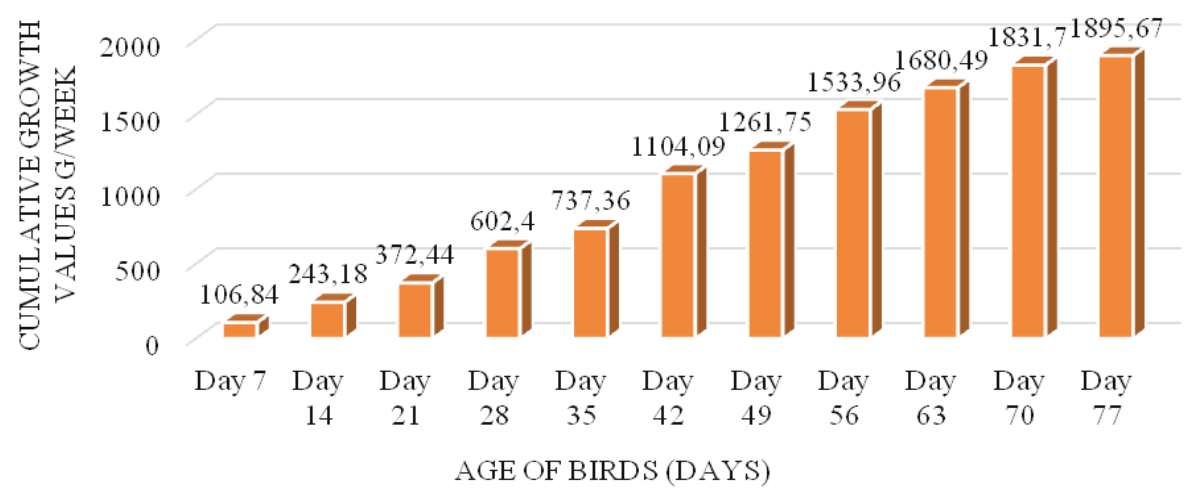

Figure 2. Dynamics of cumulative growth on the studied birds

Table 2. The consumption of combined fodder in studied birds

\begin{tabular}{ccccc}
\hline \multirow{2}{*}{ Age (weeks) } & \multirow{2}{*}{ Number of birds } & \multicolumn{2}{c}{ Average consumption (g/head) } & \multirow{2}{*}{ FCR (kg feed intake/kg BW gain) } \\
\cline { 2 - 5 } & & Per day & Cumulated & 2.04 \\
\hline $\mathbf{1}$ & 50 & 22.87 & 160.09 & 2.48 \\
\hline $\mathbf{2}$ & 50 & 48.56 & 500.01 & 3.81 \\
\hline $\mathbf{3}$ & 50 & 71.41 & 999.88 & 3.36 \\
\hline $\mathbf{4}$ & 50 & 116.97 & 1818.67 & 5.11 \\
\hline $\mathbf{5}$ & 50 & 97.12 & 2498.51 & 2.07 \\
\hline $\mathbf{6}$ & 50 & 119.00 & 3331.51 & 4.32 \\
\hline $\mathbf{7}$ & 50 & 94.21 & 3990.98 & 2.90 \\
\hline $\mathbf{8}$ & 50 & 111.41 & 4770.85 & 3.01 \\
\hline $\mathbf{9}$ & 49 & 117.13 & 5590.76 & 5.02 \\
\hline $\mathbf{1 0}$ & 48 & 114.19 & 6390.09 & 6.02 \\
\hline $\mathbf{1 1}$ & 48 & 85.69 & 6989.92 & $3.64 \mathrm{~kg} \mathrm{cf} / \mathrm{kg}$ increase \\
\hline Average & & $81.94 \mathrm{~g} / \mathrm{head}$ & & \\
\hline
\end{tabular}

homogeneity, with coefficients of variation withing the range of $6.34-9.92 \%$ (Table 1 ).

Concerning the body weight of the birds studied, the results obtained by us (1923.76 $\pm 18.29 \mathrm{~g}$ ) were well above those recorded by Bernacki et al. (2013) who found the average body weight of $1081 \mathrm{~g}$ in 12-week-old grey guinea fowl not improved for meat traits.

The daily average gain varied around $20 \mathrm{~g} /$ head/day. For this indicator, the lowest values were obtained after the first week, $11.23 \mathrm{~g} / \mathrm{head} /$ day, and the highest values were reached in the $6^{\text {th }}$ week, $53.1 \mathrm{~g} / \mathrm{head} /$ day. In the last week of our experience $\left(11^{\text {th }}\right)$, the average daily gain of our birds recorded a level of only $12.7 \mathrm{~g} / \mathrm{head} /$ day (Figure 1).

Regarding the cumulative growth, it had a steady growth, with the exception of the $21^{\text {st }}$ day, when it reached $372.44 \mathrm{~g}$ and the $49^{\text {th }}$ day with a value of $1261.75 \mathrm{~g}$. At the end of the experimental period, the cumulative weight gain was $1895.67 \mathrm{~g}$ (Figure 2).
The average consumption of combined fodder was $81.94 \mathrm{~g} / \mathrm{head}$, with values ranging from 22.87 $\mathrm{g} /$ head/day (week 1) and $119.00 \mathrm{~g} / \mathrm{head} /$ day (week 6). The lowest value was recorded in the $1^{\text {st }}$ week with $22.87 \mathrm{~g} / \mathrm{head} /$ day, after that in the $7^{\text {th }}$ week $94.21 \mathrm{~g} / \mathrm{head} /$ day and $11^{\text {th }}$ week with 85.69 g/head/day (Table 2).

The average daily feed consumption of combined birds of the experience was $81.94 \mathrm{~g}$ / head / day, resulting in a total consumption of $6989.92 \mathrm{~g} /$ head / day compared to Kerketta and Mishra (2016) obtained a combined feed consumption of $5789 \mathrm{~g}$.

For the feed conversion index, Frątczak et al. (2002) obtained values of $3.5 \mathrm{~kg}$ feed intake/ kg BW gain, Tufarelli et al. (2007) of 3.74-3.86 kg feed intake/kg BW gain, and Kerketta and Mishra (2016), of $3.74 \mathrm{~kg}$ feed intake/kg BW gain. These results were achieved with the slaughter of birds at the age of 11 weeks, similar to our experiment.

Actual losses over the entire period of the experience were $4 \%$. Two cases of mortality were 
Table 3. Stockholding proportion

\begin{tabular}{cccccc}
\hline \multirow{2}{*}{ Age (weeks) } & \multicolumn{2}{c}{ Number of birds } & Mortality & Cumulated \\
\cline { 2 - 6 } & $\begin{array}{c}\text { At the beginning of } \\
\text { the week }\end{array}$ & $\begin{array}{c}\text { At the end of the } \\
\text { week }\end{array}$ & Number & \% & 0 \\
\hline $\mathbf{1}$ & 50 & 50 & 0 & 0 & 0 \\
\hline $\mathbf{2}$ & 50 & 50 & 0 & 0 & 0 \\
\hline $\mathbf{4}$ & 50 & 50 & 0 & 0 & 0 \\
\hline $\mathbf{5}$ & 50 & 50 & 0 & 0 & 0 \\
\hline $\mathbf{6}$ & 50 & 50 & 0 & 0 & 0 \\
\hline $\mathbf{7}$ & 50 & 50 & 0 & 0 & 0 \\
\hline $\mathbf{8}$ & 50 & 50 & 0 & 0 & 0 \\
\hline $\mathbf{9}$ & 50 & 50 & 1 & 2 & 2 \\
\hline $\mathbf{1 1}$ & 50 & 49 & 1 & 2 & 4 \\
\hline
\end{tabular}

recorded in the $9^{\text {th }}$ and $10^{\text {th }}$ wee, due to mechanical accidents that caused bleeding in the internal organs, namely the liver, which, due to the onset of the fatty liver syndrome it becamed very brittle (Table 3).

The recorded mortality indicates diseases due to prolonged hypokinesia, and associated with a high energy level of compound feed, has resulted in fatty liver syndrome.

\section{CONCLUSIONS}

The final conclusion of our study is that ensuring optimum conditions of microclimate and a high quality food helps to achieve good performance in raising guinea fowl for poultry production.

\section{REFERENCES}

1. Bernacki Z, Kokoszyński D, Bawej M (2013). Evaluation of some meat traits in two guinea fowl genotypes. Arch. Geflugelk. 77: 116-122.

2. Frątczak M, Rutkowski A, Józefiak D (2002). Comparison of several diet formulas used in rearing guinea fowl. Roczniki Naukowe Zootechniki,16: 205-210.

3. Kerketta N, Mishra S (2016), Growth performance, carcass characteristics and meat quality of pearl and lavender varieties of guinea fowl (Numida Meleagris) in tropical climate of chhattisgarh, Jurnal of Veterinary Science \& Research, India.

4. Tufarelli V, Dario M, Laudadio V (2007). Effect of xylanase supplementation and particle-size on performance of guinea fowl broilers fed wheat-based diets. International Journal of Poultry Science, 6: 302-307

5. Usturoi MG (2008). Creșterea păsărilor.”Ion Ionescu de la Brad" Publishing House, Iași. 